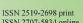

НАУКОВИЙ ВІСНИК

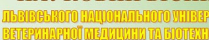

Sientific messenger of L Lviv National Unive

Veterinary Wedcline and Biotechnologis

(n)

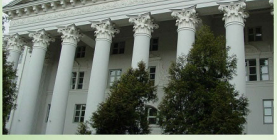

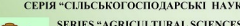

Том 23 № 94 2021
Науковий вісник Дьвівського національного університету ветеринарної медицини та біотехнологій імені С.3. Гжицыкого. Серія: Сільськогосподарські науки

\section{Scientific Messenger of Lviv National University} of Veterinary Medicine and Biotechnologies. Series: Agricultural sciences

https://nvlvet.com.ua/index.php/agriculture

UDC 581.52(630*181)

\title{
Functional adaptation of Quercus robur L. and Cercidiphyllum japonicum Siebold et Zucc. in the urban landscapes of Lviv
}

\author{
P. S. Hnativ ${ }^{1}$, B. V. Gutyj ${ }^{2}$, G. A. Lysak ${ }^{1}$, N. Y. Lopotuch ${ }^{1}$, R. S. Shkumbatyk ${ }^{1}$ \\ ${ }^{1}$ Lviv National Agrarian University, Lviv, Ukraine \\ ${ }^{2}$ Stepan Gzhytskyi National University of Veterinary Medicine and Biotechnologies Lviv, Ukraine
}

Article info

Received 22.02.2021

Received in revised form 22.03.2021

Accepted 23.03.2021

Lviv National Agrarian University, Great Vladimir Str., 1, Dubliany,

Zhovkva district, L'viv region,

80381, Ukraine.

Tel.: + 38-032-22-42-335

E-mail:pshnativ@ukr.net

Stepan Gzhytskyi National University of Veterinary Medicine and Biotechnologies Lviv,

Pekarska Str., 50, Lviv,

79010, Ukraine.
Hnativ, P. S., Gutyj, B. V., Lysak, G. A., Lopotuch, N. Y., \& Shkumbatyk, R. S. (2021). Functional adaptation of Quercus robur L. and Cercidiphyllum japonicum Siebold et Zucc. in the urban landscapes of Lviv. Scientific Messenger of Lviv National University of Veterinary Medicine and Biotechnologies. Series: Agricultural sciences, 23(94), 93-99. doi: 10.32718/nvlvet-a9417

The general trends in the purity changes of the environment in connection with the urbanistic technogenesis were analyzed on the example of the largest city of Western Ukraine - Lviv - and its outskirts, Dublyany. The characteristic changes of some parameters of the main environmental factors - transformed ecosystems, including biogeochemical properties of edaphotope and pollution by heavy metals are described. Urbanization leads to a tendency of parkerising, alkalinization and significant measure of green zone soil contamination with heavy metals. The increase of the complex pressure of urban anthropogenic environment on vegetation is revealed and current changes of the chemical composition of dry matter of leaves of trees in terms of heavy metal content and structure-energy metabolites are analyzed. A significant accumulation of some chemical elements in the assimilation system of Quercus robur L. and Cercidiphyllum japonicum Siebold et Zucc. was found, their species-specific features of ash accumulative ability were revealed. Cercidiphyllum japonicum is proved to be a promising and effective, in terms of cleaning the environment from man-made pollution, decorative plant in the green belt of cities in the regions of Roztochchia and Pasmove Pobuzhya. Under the influence of edaphotope transformation and pollution in the assimilation bodies of woody plants some structural and metabolic changes occur to adapt to the new to their species environment. Oak as autochthonous species, has signs of stability of the metabolic system of assimilation to the urban genic changes. Cercidiphyllum's structure demonstrates plasticity of dry matter of leaves, designed to adapt to the new environment acclimatization of exotic species, and thus performs an effective metal storage function in a green area of the city.

Key words: soil, heavy metals, assimilation, adaptation of plants, greening the city.

\section{Функціональне пристосування Quercus robur L. та Cercidiphyllum japonicum Siebold et Zucc. в урболандшафтах Львова}

\author{
П. С. Гнатів ${ }^{1}$, Б. В. Гутий ${ }^{2}$, Г. А. Лисак ${ }^{1}$, Н. Я. Лопотич ${ }^{1}$, Р. С. Шкумбатюк ${ }^{1}$ \\ ${ }^{1}$ Львівський начіональний аграрний університет, м. Львів, Україна \\ ${ }^{2}$ Львівський національний університет ветеринарної медицини та біотехнологій імені С. 3. Гюсицького, м. Львів, \\ Украӥна
}

На прикладі найбільшого міста заходу Украӥни Львова та Дублян виявлені тендениї зміни якостей навколишнього природного середовища в зв'язку з урботехногенезом та забрудненням. Урбанізація зумовлює тенденцію до фосфатизації, алкалізації та вагомого забруднення трунтів зеленої зони важкими металами. Показано зростання комплексного тиску урботехногенного середовища на рослини і проаналізовані актуальні зміни хімічного складу сухої речовини листків дерев за показниками вмісту важких металів та структурно-енергетичних метаболітів. 3'ясовано істотне накопичення хімічних елементів в асиміляційному апараті дуба звичайного та багряника японського, виявлені їх видоспецифічні особливості шзодо золоакумулятивної здатності. Обтрунто- 
вано перспективність багряника японського, як ефективної з точки зору очищення довкілля від забруднень, декоративної породи у зеленій зоні міст регіону Розточчя і Пасмового Побужжя. Під впливом трансформації едафотопа й забруднення в асиміляиійних органах деревних рослин відбуваються структурно-метаболічні зміни, спрямовані на пристосування видів у новому для них довкіллі. Дуб звичайний має ознаки стійкості метаболізму асимілячійних органів до урбогенних змін. Багряник японський має пластичну структуру сухої речовини листків, динамічно змінює ї̈ у новому для інтродуцента середовищі акліматизації $і$, при иьому виконує ефективну металоакумуляиійну функиію у зоні міста.

Ключові слова: трунт, важкі метали, асиміляція, адаптац̧ія рослин, озеленення міста.

\section{Вступ}

Системні аутекологічні взаємовідношення організму й середовища реалізуються, як основа адаптивних реакцій рослин, що ростуть в урбаністичних екосистемах сучасних міст. Теперішне антропогенне навколишнє середовище (Korshykov, 1996; Mirzak, 2002; Korshykov \& Gnativ, 2003; Kucherjavyj, 2003; Jevsieieva et al., 2011; Voloschyns'ka, 2012; Hnativ, 2012; 2014) є спотвореним як стосовно життєвих функцій рослин, так і біоти загалом. Антропогенне збурення в довкіллі супроводжується ланцюговими змінами в органах і процесах живих систем і визначає позитивні чи негативні перспективи пристосування деревних рослин у ньому (Hnativ et al., 2019).

В урбаністичних системах рослинам належить потужна середовищестабілізаційна роль (Korshykov, 1996; Hnativ, 2014). Зелені насадження сприяють значному оздоровленню середовища їхнього росту, яке є і середовищем життя людини. Контактна поверхня рослинної маси у Львові досягає 37-161 тис. м² га $^{-1}$, індекс листкової поверхні - 2,4. На сьогодні площа насаджень навколо Львова становить 33,3 тис. га, а безпосередньо в межах міста - 4,4 тис. га. Водночас сьогодні гостріше проявляється тенденція збіднення з різних причин таксономічного різноманіття міських насаджень попри іiі багатство у ботанічних садах.

Мета дослідження - виявлення антропогенних змін навколишнього природного середовища у Львові та з'ясування їхнього впливу на стійкість і функціональне пристосування в ньому деревних рослин.

\section{Матеріал і методи досліджень}

Вибір модельних ділянок здійснили з урахуванням умов, які максимально відображають типові (Hnativ, 2014): вуличні лінійні насадження (дуб звичайний Quercus robur L. по вул. Глибокій, багряник японський - Cercidiphyllum japonicum Siebold et Zucc. по вул. Угорській), які завантажені транспортними потоками у густозаселених житлових масивах; паркові насадження (Ботанічний сад Національного лісотехнічного університету України (НЛТУУ) - частина зеленої зони Львова); заміські насадження (парк Львівського національного аграрного університету (ЛНАУ м. Дубляни), який вважаємо районом, наближеним до малозмінених екоумов.

Властивості грунту визначали за такими показниками: вміст гумусу (ДСТУ 4289. 2004); реакція грунтового розчину (ДСТУ 10390: 2001); доступні форми фосфору і калію (ДСТУ 4405: 2005); обмінні катіони кальцію та магнію - за методикою ЦІНАО (ГОСТ 26487-85); уміст азоту лужногідролізованого - за
Корнфільдом. Вміст важких металів у грунті визначали на атомно-абсорбційному спектрофотометрі С 115 $1 \mathrm{M} \mathrm{у} \mathrm{полум'ї} \mathrm{“ацетилен-повітря”.} \mathrm{Аналізи} \mathrm{виконали}$ методами ЦІНАО (Metodicheskie ukazaniya..., 1992) на базі Львівського проектно-технологічного центру “Держгрунтохорона".

Для дослідження показників життєдіяльності деревних рослин обрані групи особин 3 максимально близькими морфолого-біометричними ознаками (710 особин однакового віку). 3 кожної видової групи у кожній точці відбору за допомогою телескопічної штанги довжиною 5 м відбирали 25-35 типових за розмірами і виглядом, здорових листків. Предметом дослідження є зміни метаболічного складу сухої речовини листків у пік їхньої літньої фізіологічної активності. Аналізували зразки з дворазовою повторністю за такими показниками (Pochynok, 1976): зола (“мокрим" озолінням за Лебедянцевим), клітковина (за Геннебергом-Штоманом), ліпіди (за Рушковським) у відсотках на суху речовину. Вміст водорозчинних цукрів визначали за Бертраном з відновленням окису міді. Запаси крохмалю в листках аналізували осадженням йодом (біхроматометричний метод). Загальний азот визначали за К'єльдалем і перераховували на вміст протеїдів (білків і азотовмісних речовин) Вміст безазотистих екстрактивних речовин (БЕР) розраховували як різницю між сумою всіх визначених аналітичним шляхом органічних і мінеральних компонентів та кількістю абсолютно сухої речовини листків (Hnativ, 2014). Статистичне опрацювання даних виконали з використанням MS Excel, Statistica.

\section{Результати та їх обговорення}

Мезоклімат Пасмового Побужжя Західноукраїнської широколистянолісової зони сприятливий для вирощування й інтродукції широкого асортименту декоративних деревних видів. Поряд 3 цим, в умовах міст, зокрема, такого великого як Львів, де забудова займає площу близько 12 тис. га, локальні кліматичні умови $є$ істотно змінені. 3 цієї причини едафотопи (переважно чорноземи опідзолені і темно-сірі опідзолені грунти) у насадженнях Львова істотно змінені. Зокрема, аналізи агрохімічних властивостей профілю трансформованих грунтів до глибини 0-20 см свідчать (табл. 1), що урбоземи Львова бідніші за вмістом гумусу, азоту й магнію. Проте, едафотоп вулиці Львова найбагатший за вмістом рухомого фосфору, обмінного калію й кальцію, має близьку до нейтральної реакцію і містить найбільшу кількість основ, що свідчить про потужну емісію в грунти міста біофільних та інших сполук. 


\section{Таблиця 1}

Зміни вмісту гумусу й доступних поживних речовин в 0-20 см пласті грунтів зелених зон Львова й Дублян (помилка паралельних аналізів не перевищує 5 \%-й рівень значущості).

\begin{tabular}{|c|c|c|c|c|c|c|c|c|c|}
\hline Модельний об’єкт & $\sum_{\substack{\vdots \\
\vdots}}^{\circ}$ & 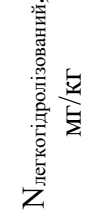 & 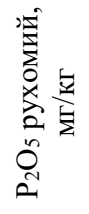 & 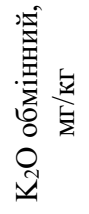 & 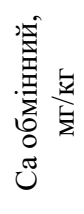 & 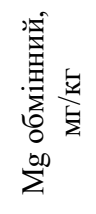 & 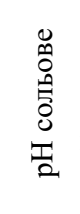 & $\begin{array}{c}\text { Гідролі- } \\
\text { тична кис- } \\
\text { лотність, } \\
\text { мг-екв/100 г грун- } \\
\text { ту }\end{array}$ & $\begin{array}{c}\text { Сума ввібраних } \\
\text { основ, } \\
\text { мг-екв/100 г грун- } \\
\text { ту }\end{array}$ \\
\hline Зелена зона м. Дубляни & 3,27 & 109,2 & 125 & 115 & 5,0 & 1,8 & 4,95 & 4,92 & 13,75 \\
\hline $\begin{array}{l}\text { Парк Ботанічного саду НЛТУ України } \\
\text { (м. Львів) }\end{array}$ & 2,28 & 100,8 & 62 & 101 & 6,7 & 1,0 & 5,10 & 4,05 & 13,75 \\
\hline Вулиці м. Львів & 2,74 & 103,6 & 128 & 175 & 8,5 & 0,7 & 6,13 & 2,74 & 30,00 \\
\hline
\end{tabular}

Вуличні едафотопи за важливими для рослин показниками є сприятливішими для мінерального живлення, ніж бідніші грунти парку Ботанічного саду НЛТУ України. Проте, їх несприятливі водно-фізичні властивості нівелюють певні агрохімічні переваги (Kucherjavyj, 2003). Отже, залежно від ступеня інженерного перетворення (технозем, техногрунт, тверде покриття, забудова) істотно змінюються умови мінерального живлення рослин урбанізованих територій (Mirzak, 2002; Korshykov \& Gnativ, 2003; Kucherjavyj, 2003; Hnativ, 2014).
Сучасною особливістю міських i техногенних ландшафтів є значне забруднення (Korshykov \& Gnativ, 2003; Jevsieieva et al., 2011; Voloschyns'ka, 2012). Зокрема, у Львові час від часу концентрація бенз(а)пірену в повітрі у два рази перевищувала ГДК, свинцю - у три, міді - у п’ять разів (Hnativ, 2012; 2014). За нашими дослідженнями найвиразніше та прямолінійно зростає забруднення грунтів цинком, свинцем і кадмієм за переміщення від околиці Львова (Дубляни), до Ботанічного саду та центральних вулиць (рис. 1).

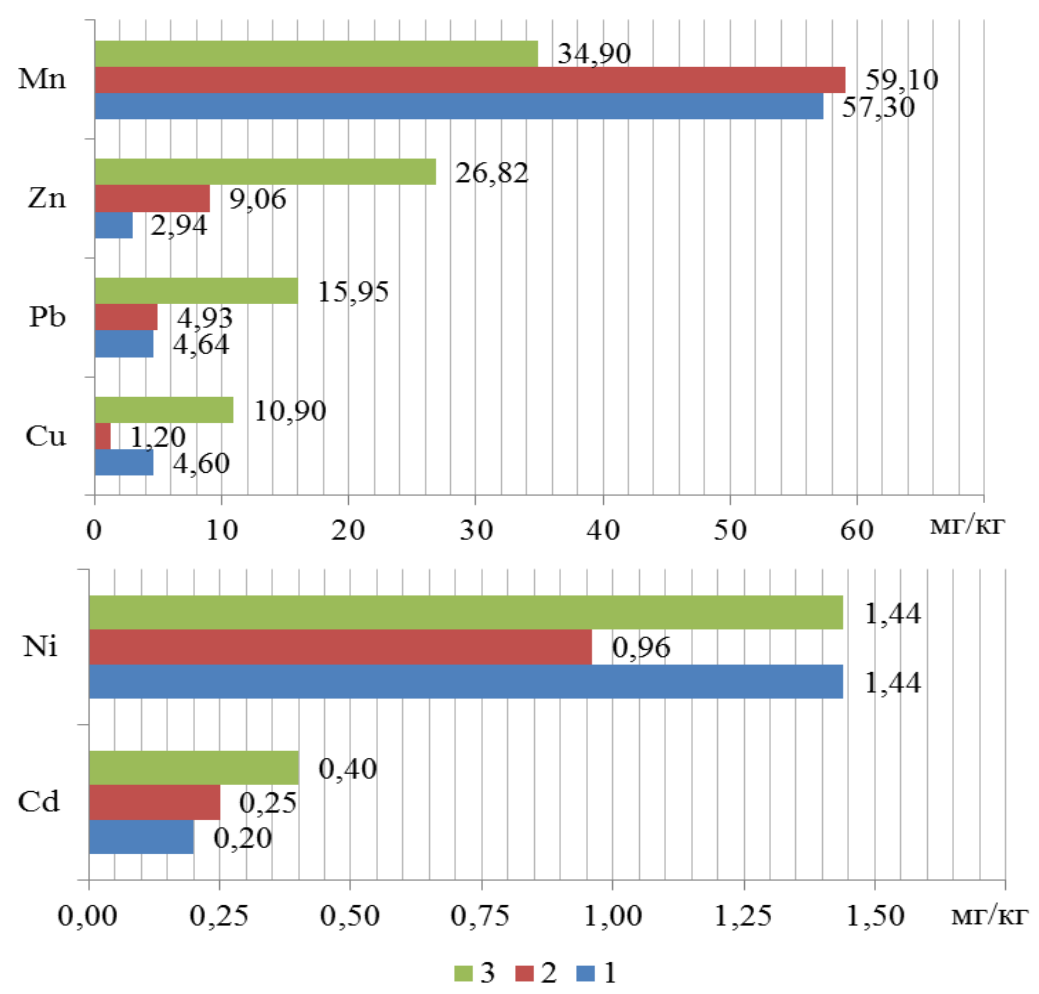

Рис. 1. Вміст рухомих форм деяких важких металів в грунтах Львова і Дублян, мг/кг:

1 - зелена зона м. Дубляни; 2 - парк Ботанічного саду НЛТУ України; 3 - вуличне насадження м. Львів

В едафотопі насадження вулиці міститься найбільше, порівняно з іншими модельними насадженнями, міді, цинку, свинцю, кадмію і нікелю. Це підтверджує існування інтенсивного техногенного пресу на довкілля Львова, особливо у центрі міста.
Під впливом техногенного забруднення, зокрема, викидів транспорту зростає вміст низки елементів у фотосинтетичному апапраті рослин (рис. 2). 


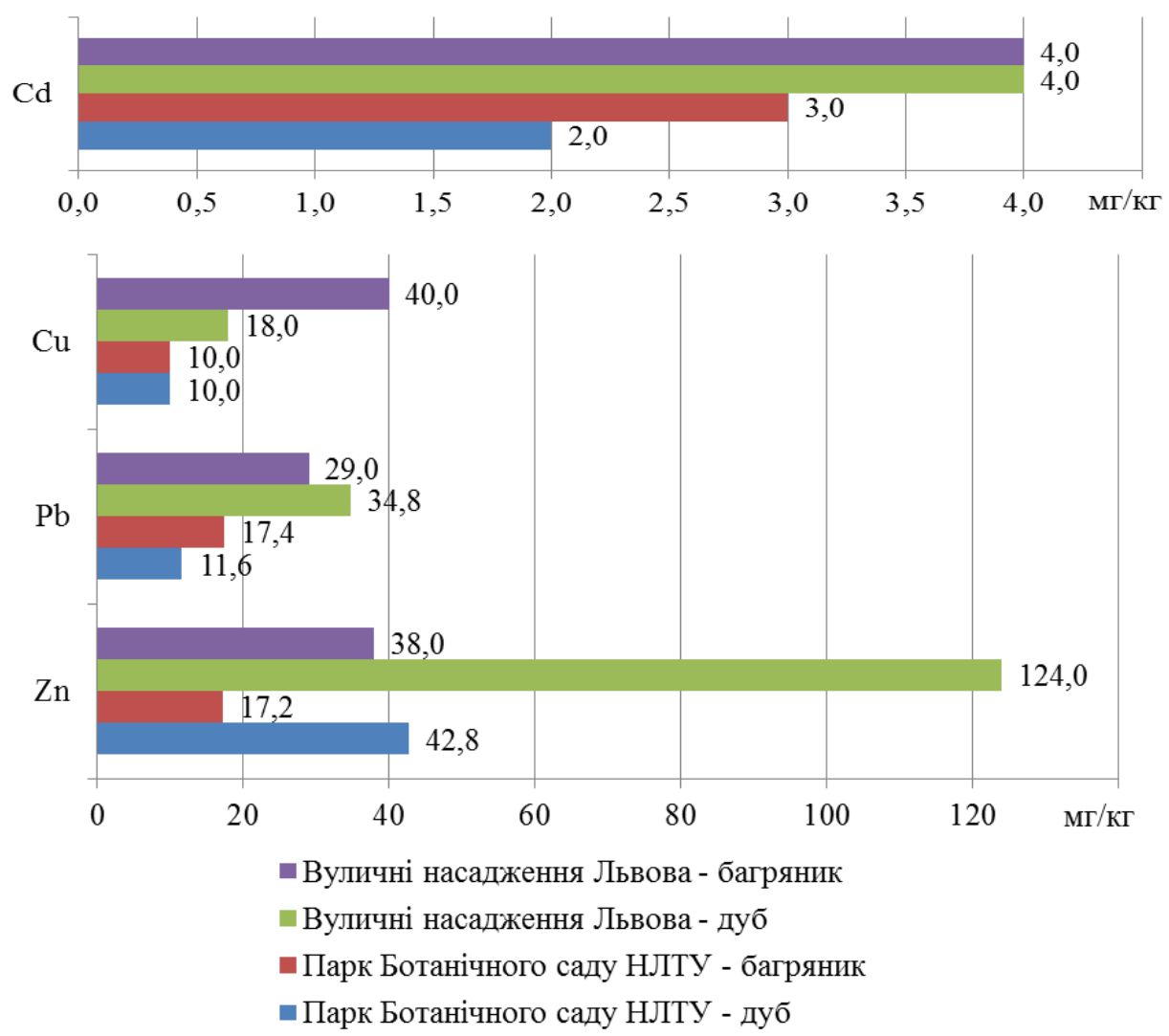

Рис. 2. Вміст важких металів $\mathrm{Cd}, \mathrm{Cu}, \mathrm{Pb}$ та $\mathrm{Zn}$ в золі листя, мг/кг на сухої речовини

У Львові, порівняно з чистою територією парку Дублян, спостерігаємо забруднення листків дерев важкими металами - особливо цинком і свинцем, а також міддю і кадмієм. Дуб звичайний має властивість нагромаджувати в асиміляційних органах значно більшу кількість цинку й свинцю, ніж багряник японський. Проте цей інтродуцент значно активніше, ніж у парках Дублян чи Львова, засвоює досліджені важкі метали в умовах насаджень вулиці.

За нашими попередніми дослідженнями (Hnativ, 2014) дуб звичайний, липа серцелиста, клен гостроли- стий, які зростають у приміському лісі, акумулювали у сухій масі листків менше зольних речовин, ніж у парку Львова. Отже, найсильніша забрудненість середовища вулиці зумовила максимальне надходження зольних сполук у листки дуба й багряника, як і інших видів.

Аероемісійний тиск на фотосинтетичний апарат дерев і зміни в едафотопі призводить до того, що в багряника сильніше, а в дуба слабкіше, проявляється тенденція до засвоєння золи і зольних елементів (рис. 3).

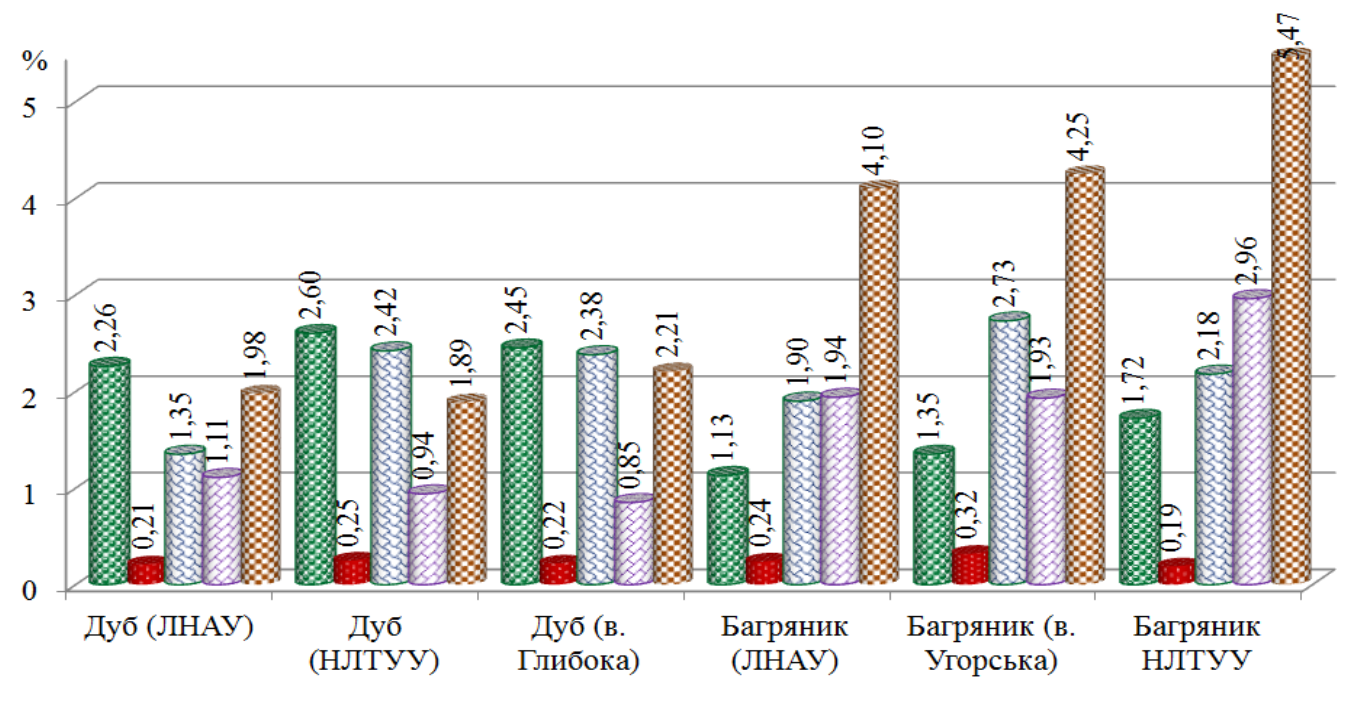

Азот Фосфор

Рис. 3. Асиміляція зольних елементів і золи загалом листками деревних видів у різних умовах росту 
Загалом багряник японський виявився у двічі активнішим щодо поглинання мінеральних речовин. 3 одного боку це свідчить про краще мінеральне живлення виду в умовах акліматизації у Львові, а з іншого дерева цього виду $\epsilon$ набагато потужнішими нейтралізаторами хімічних сполук як з грунту, так частково і 3 повітря. Адже вагома частина елементів потрапляє в листки шляхом позакореневого живлення (Hnativ, 2012; 2014). Будучи ефективнішим акумулятором забруднень багряник все ж втрачає ці властивості у критичних умовах росту - вуличних насадженнях, тоді як дуб звичайний і в лінійних насадженнях підвищував концентрацію зольних елементів у листках.

Асиміляція азотних сполук як у дуба (2,26 \% сухої речовини листків), так і в багряника $(1,13 \%)$ мінімальна в умовах зеленої зони м. Дубляни, де практично відсутне атмосферне забруднення оксидами азоту, хоча грунт тут найбагатший азотом і гумусом 3-поміж досліджуваних насаджень. Умови паркових насаджень Львова, як видно на прикладі Ботанічного саду НЛТУУ, сприяють активізації асиміляції азоту дубом до 2,60 \% сухої речовини листків, проте у багряника це більше помітно (підвищення на $0,57 \%$ ), адже його у листках рослин у Дублянах найменше. Обидві деревні породи зменшують нагромадження азоту у найскладніших екоумовах насаджень вулиць Львова: дуб до $2,45 \%$, багряник до $1,35 \%$ на суху речовину. Отже, інтродукований у Львові й Дублянах багряник японський засвоює менше азоту, порівняно з аборигеном дубом звичайний і стрімкіше реагує на антропізацію природного довкілля.

3D-модель регресії забезпеченості рослин дуба звичайного та багряника японського азотом залежно від асиміляції фосфору та калію в умовах міста візуалізує площину закономірності покращення азотного живлення на тлі мінімального забезпечення фосфором (рис. 4). За доброї забезпеченості калієм засвоєння рослин азотом практично покращується. Встановлену закономірність описує математична модель залежності асиміляції азоту $\mathrm{N}=2,8867+0,3001 \times \mathrm{P}-6,7834 \times \mathrm{K}$ від забезпеченості рослин фосфором та калієм.

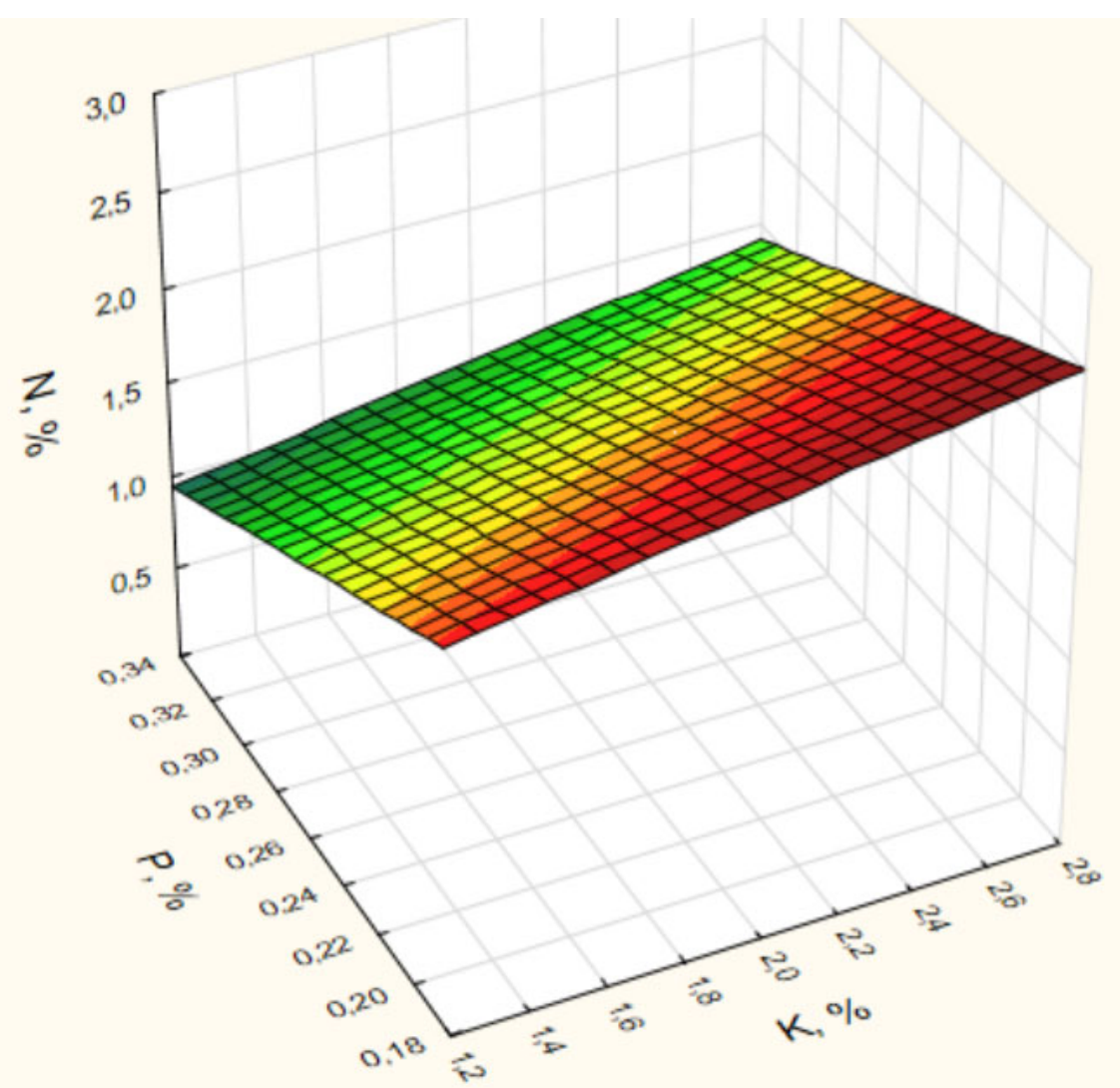

Рис. 4. 3D-модель регресії забезпеченості рослин азотом залежно від асиміляції фосфору та калію в умовах міста ( $\mathrm{N}=$ найменші квадрати, зважені на відстань)

Таким чином, в антропізованих екосистемах, прикладом яких є урбоекосистема Львова, істотно зміщуються параметри атмосферних факторів (складу й температури повітря), змінюються фізико-хімічні показники, пришвидшується дегуміфікація, посилюється фактор техногенного забруднення (атмосфери, грунту, атмосферної і грунтової води, органів рослин і фітомаси загалом). Це все вагомо впливає на внутрішні процеси в рослинах і змінюе співвідношення компонентів метаболізму й асиміляції речовин у листках дерев (Hnativ, 2012; 2014).

Зокрема наші дослідження показали, що спектри структурних та енерго-пластичних речовин листків у виду-едифікатора місцевих екоумов та акліматизованого інтродуцента істотно відрізняються (рис. 5). Виразна видова відмінність встановлена за показником пропорції клітковини. 


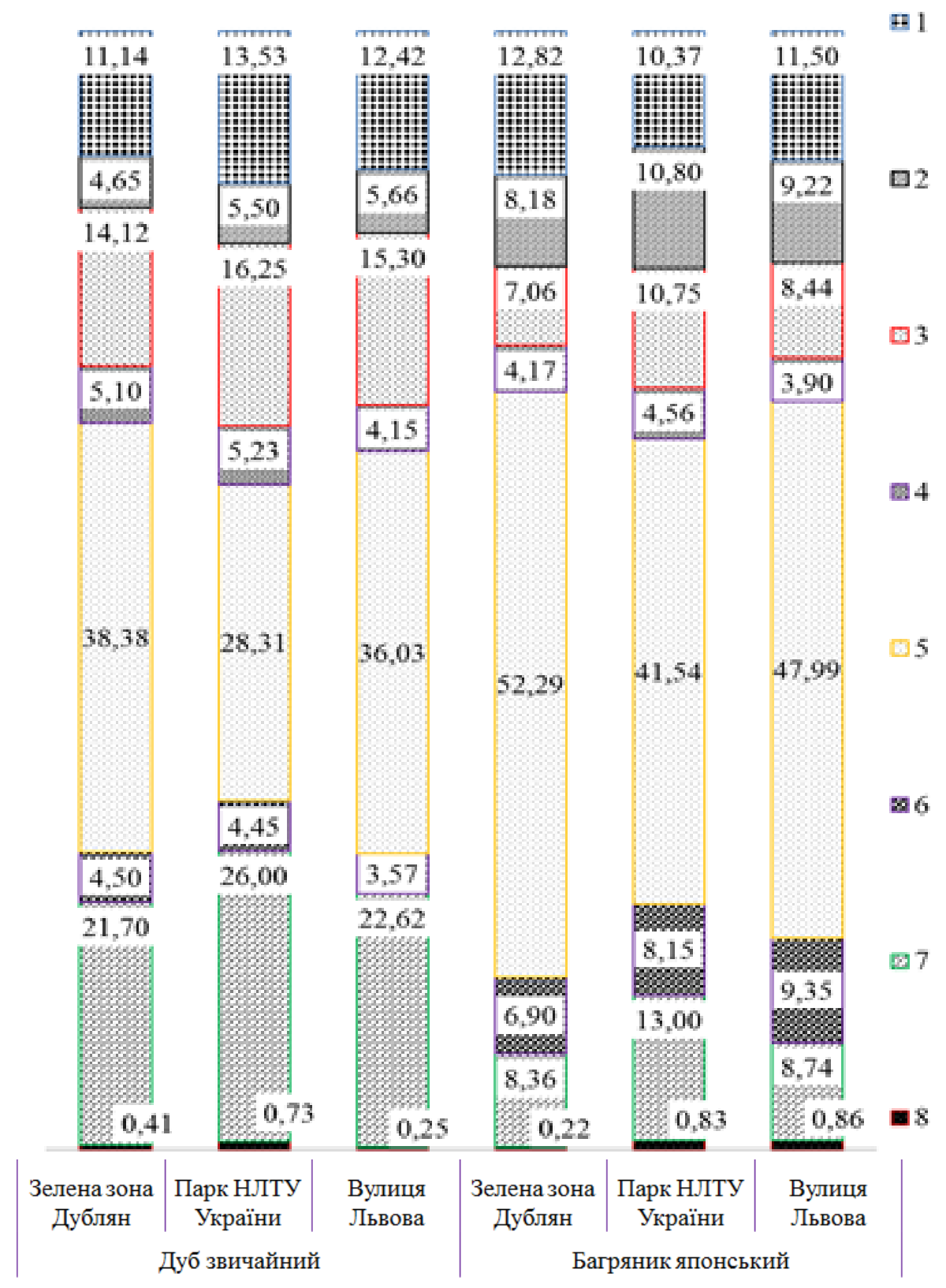

Рис. 5. Спектри хімічного складу сухої речовини листків деревних видів за пропорціями метаболітів у різних умовах росту (\%): 1 - волога; 2 - зола; 3 - білки та азотовмісні сполуки; 4 - цукри; 5 - безазотисті екстрактивні речовини; 6 - крохмаль; 7 - клітковина; 8 - ліпіди

У дуба звичайного ії майже втричі, а в умовах парку Львова вдвічі більше, ніж у багряника японського. Натомість, водорозчинних вуглеводів, у тому числі самих лише безазотистих екстрактів, листки багряника містять приблизно на третину більше, ніж листки дуба. Дуб, який у різних умовах росту, в силу своєї видової особливості помірно засвоювати золу і асимілювати більше азоту, ніж багряник, утворює більшу кількість білків. Акліматизований багряник має інші пропорції енерго-пластиних речовин, але проблем пристосування не виявляє. Це свідчить про більшу адаптованість аборигена до своїх природних умов росту за співвідношеннями структурних і водорозчинних вуглеводів у сухій речовині листків (Hnativ, 2012; 2014).
Підвищені резерви цукрів у формі крохмалю у листках багряникаа засвідчують певні труднощі у метаболізмі вуглеводів або ж проблеми з їх переміщенням по рослині, особливо у найскладніших умовах вулиці Львова. Такі реакції рослин на складні умови росту були виявлені дослідженнями попередніх років на багатьох деревних видах, у тому числі на багрянику японському (Hnativ, 2014). Проте його здатність активніше асимілювати зольні сполуки свідчить про потужну санувальну функцію насаджень 3 домінуванням багряника в умовах підвищеного забруднення техногенними викидами у великих містах.

Основою ослаблення стабільності екосистем різного рангу (стійкості й адаптації їх деревних компонентів) $є$ порушення структури й функції рослинного покриву. Перетворення природного середовища Льві- 
вщини в урботехногенне, як і в потужніших промислових регіонах, стає новим фактором адаптогенезу рослин в антропогенному середовищі (Korshykov, 1996; Korshykov \& Gnativ, 2003; Hnativ, 2014). Тому використання інтродуцентів, добре пристосованих і функціональних у складних умовах, надасть можливість покращувати якість перетвореного довкілля у великих містах.

Змінюючи біогеохімічні показники трофності грунтового профілю 0-20 см, концентрацію важких металів ( $\mathrm{Cu}, \mathrm{Zn}, \mathrm{Pb}, \mathrm{Cd}, \mathrm{Ni})$ у ньому, техногенні емісії збільшують надходження їх у листки дерев. Особливо виразно це простежуємо у багряника японського за вмістом міді й у дуба за вмістом цинку. Дуб звичайний в екотопі парку Ботанічного саду НЛТУ України (найкращі для дерев умови зеленої зони Львова) нагромаджував цинку вагомо більше, а в насадженнях вулиці міста - у тричі більше, ніж у зеленій зоні м. Дубляни.

\section{Висновки}

Техногенне забруднення і зміна властивостей едафотопів в урболандшафтах Львівського східного району Пасмового Побужжя сукупно доволі виразно впливають на функціональний стан рослин і властивості грунту.

Багряник японський у зеленій зоні як Дублян, так і Львова, асимілював приблизно у двічі більше усіх зольних сполук, ніж дуб звичайний. У такий спосіб цей деревний вид, зв'язуючи хімічні елементи і важкі метали у тканинах листків і сануючи у такий спосіб повітря і грунт, значно корисніший в озелененні. Така утилізаційна ефективність акліматизованого інтродуцента пригнічувала синтез клітковини у листках, спричиняла ріст у тканинах кількості водорозчинних вуглеводів і запасу крохмалю. Проте, це не позначалося негативно на його рості й розвитку, на декоративності і на габітусі крони. Водночас, виразне розбалансування складу сухих речових, порівняно з дубом звичайним, може служити індикатором негативних змін трансформованого довкілля, або гірших природних умов росту інтродуцента, адже в оптимальних умовах парку Ботанічного саду Львова спектр метаболітів у листках багряника мав найкраще їх співвідношення.

\section{References}

Hnativ, P. S. (2012). An euthrophication of transformation ecotopes by the indexes of nitric and phosphoric feed of arboreal plants. Forestry and landscape gardening, 2.

Hnativ, P. S. (2014). Funkcional'na diagnostyka v dendroekologii [Functional diagnosis in dendroecology]. Lviv (in Ukrainian).
Hnativ, P. S., Balkovskyy, V. V., Lopotych, N. Y., \& Datsko, T. M. (2019). Technological and urban systems: methodological approaches to the assessment of the condition of urbanized environment. Scientific Bulletin of UNFU, 29(5), 82-87. doi: 10.15421/40290516.

Jevsieieva, M. V., Zvuzdecka, N. S., \& Panchenko, T. I. (2011). Ekologichna bezpeka gruntiv prydorozhnoii zony za vmistom spoluk svynciu [Environmental safety zone roadside soil on the content of lead compounds]. Collection of the scientific articles of "III of Allukrainian convention of environmentalists with international participation", 2, 622-624. URL: http://eco.com.ua/content/ekologichna-bezpekagruntiv-pridorozhnoi-zoni-za-vmistom-spoluksvintsyu (in Ukrainian).

Korshykov, I. I., \& Gnativ, P. S. (2003). Urbotehnogenne seredovysche jak integral'nyj chynnyk prystosuvannia roslyn [Urbotechnogenic environment as an integral factor in adaptation of plants]. Industrial ecology, 3, 78-82 (in Ukrainian).

Korshykov, Yu. Yu. (1996). Adaptaciya rastenij k usloviyam technogenno zagryaznennoj sredu [Adaptation of plants to the terms of technogenic muddy environment]. Scientific thought (in Ukrainian).

Kucherjavyj, S. V. (2003). Vulychni nasadzhennia V systemi ozelenennia Lvova i ekologichni osoblyvosti jih rozvytku [Street spaces are already greening in Lviv and ecological features of their development]. Sciences announcer of Ukrainian SFEU, 11(5), 323326. URL: https://nv.nltu.edu.ua/Archive/2001/11_5/ 72.pdf (in Ukrainian).

Metodicheskie ukazaniya po opredeleniyu tyazheluch metallov $\mathrm{v}$ pochvax sel choz ugodij i produkcii rastenievodstva (1992). [Methodical pointing on determination of heavy metals in soils of farm lands and products of plant-grower]. Moscow (in Russian).

Mirzak, O. V. (2002). Ekologichni osoblyvosti edafotopiv urbanizovanyh terytorij stepovoji zony Ukrajiny (na prykladi mista Dnipropetrovs'ka) [Environmental features edafotops urban areas steppe zone of Ukraine (on the example of Dnepropetrovsk)]. Dnipropetrovsk (in Ukrainian).

Pochynok, Kh. M. (1976). Metody biochimicheskogo analiza rasteni. [Methods of biochemical analysis ofplants]. Sciences thinking, 5-77 (in Russian).

Voloschyns'ka, S. S. (2012). Vazhki metaly v gruntah urboekosystemy $\mathrm{m}$. Kovelia [Heavy metals in soils urboecosystem c. Kovel]. Scientific announcer of the Chernivtsi university. Biology (Biological systems), 4(2), 145-148. URL: http://ibhb.chnu.edu.ua/uploads/ files/vb/BS_T4_V2_2012/4_C_145-148_Volojynska.pdf (in Ukrainian). 